\title{
Development of the underground erosion of the soils adjoining the concrete constructions (on the example of Zagorsk pumped storage power plant, ZPSPP-2)
}

\author{
Andrey Lavrusevich* and Ivan Lavrusevich \\ Moscow State University of Civil Engineering, Yaroslavskoe shosse, 26, Moscow, 129337, Russia
}

\begin{abstract}
The matter of such a dangerous geological process as suffosion is briefly considered in the article. Some examples of destruction and removal of the suffusion unstable breeds on the contact with the concrete structure are given. Sone cases of vertical (downward and upward) and sloping streams in relation to a concrete construction are considered. It is proved that after the formation of the primary underground channel the suffosion process passes into the erosive one. This transition is smoothly and gradual, hidden from the immediate observation. However, the erosive process development leads to the repeated increase in the intensity of the incoherent soil destruction. In case of existence of soil removal zone, not only the large underground channel is formed, but also large cavities in the zone of contact of the concrete structure and the soil massif are formed. It quite often leads to the emergency situations. Studied the example of the Zagorsk PSPP-2 (ZPSPP-2). The development of the erosive process under the ZPSPP-2 building led to the formation of large cavities (up to $10 \mathrm{~m}$ ) and to the general subsidence of the building of the plant and of the retaining wall 3 (RW3) on $1.17 \mathrm{~m}$ down.
\end{abstract}

\section{Introduction}

On the one hand, the suffosion is included in the list of natural influences, dangerous to construction, along with such processes as landslides, karst and processing of reservoirs shores, on the other hand, it is considered only in the paragenesis with them and it is not recognized as the self-contained geological process [1, 2, 3]. According to the Construction Regularities 116.13330.2012, the suffosion is the destruction and removal of separate components and large mass of the disperse and hardpan detrital breeds, including composing building blocks of rocky massifs, by a stream of ground waters [4]. Upon the formation of the channel, connecting the entrance cavity, through which water enters, with the area of removal the mechanical suffosion takes the form of the underground erosion, which is meant to be the destructions of rocks, caused by the suffosion, including the erosion of the bottom of the channels by running water [3]. The process of destruction of

\footnotetext{
Corresponding autour: lavrusevich@yandex.ru
} 
breeds is intensified repeatedly. The separation of the particles and units of the soil with their subsequent movement along the stream to the area of removal is facilitated. Sands, sandy loams and loessial breeds are the easiest to be washed away [5].

\section{Materials and Procedures}

The power impact of the stream of underground water on the disperse breeds is the result of the mechanical suffosion. The conditions, necessary for the development of the mechanical suffosion are, first of all, the structural-and-textural inhomogeneity of rocks (soils), the stream of underground water, having a definite hydrodynamic force, the existence of area of removal of the destroyed and moved breeds. The suffosion of technogenic character considerably dominates over the natural one and it is connected with separate hydraulic engineering structures, transport arteries, facilities of power engineering and industrial enterprises $[3,6,7]$.

During the research of the loessial pseudo-karst, the phases of the mechanical suffosion were allocated by V.P. Homenko for the suffosion cycle have been added. Two more stages have been allocated: they are the complete one and terminating one [8]. Thus, the mechanical suffosion goes through the following main organic stages: the active stage, reactive (latent and expressive) stage, and the underground erosion in the complete stage. In generally, the dynamics of degradation of the massif with volume $\mathrm{V}$, put by the suffosion unstable breeds, during the period $\mathrm{T}$, can be presented in the form of the monotonic nonlinear S-shaped function, in particular, in the form of the exponential sigmoid (Fermi function) [9].

The suffosion-and-erosive destruction of soils needs to be considered within the uniform natural-and-technical "soil-and-construction" geosystem. The underground erosion, which develops in the zone of contact with the concrete structure, depending on the spatial arrangement of the erosive channel and on the direction of water driving includes vertical (downward and upward) and inclined or horizontal suffosion-and-erosive streams. The intensity of the process also depends on the connectivity of soils and hydrodynamic force of the stream.

In case of the vertical direction of the underground erosive channel in the incoherent soils the water stream with a certain hydrodynamic force, can be downward and upward. The vertical downward erosive water stream is located sideways from the concrete structure C-1 with the gradual removal of particles from the massif and with the formation of a cavity. Then, the inclined type of the water stream forms the longitudinal channel (cavity) under the concrete structure C-2. The vertical upward water stream C-3 is similar to the downward one, but it is characterized with the opposite direction of water driving and removal of soil particles at the expense of great hydrodynamic pressure (Figure 1). 
C-1
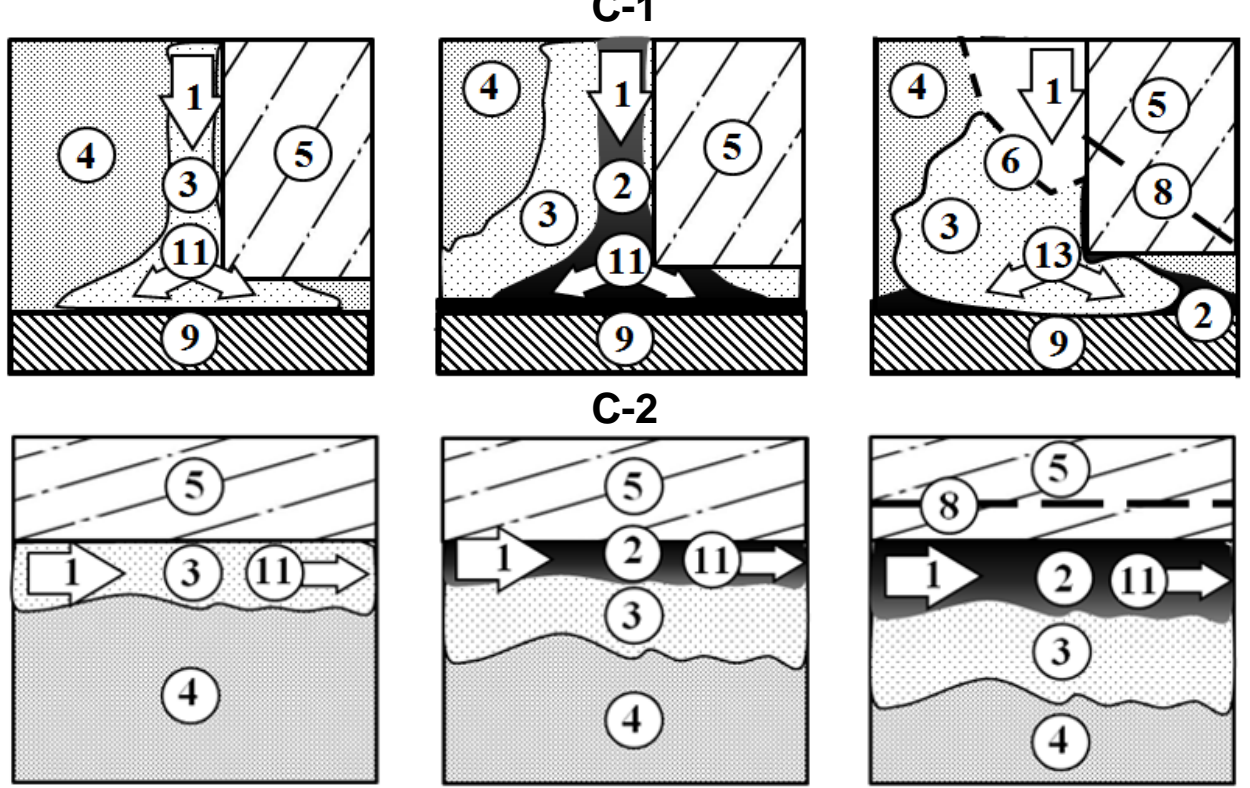

\section{C-3}
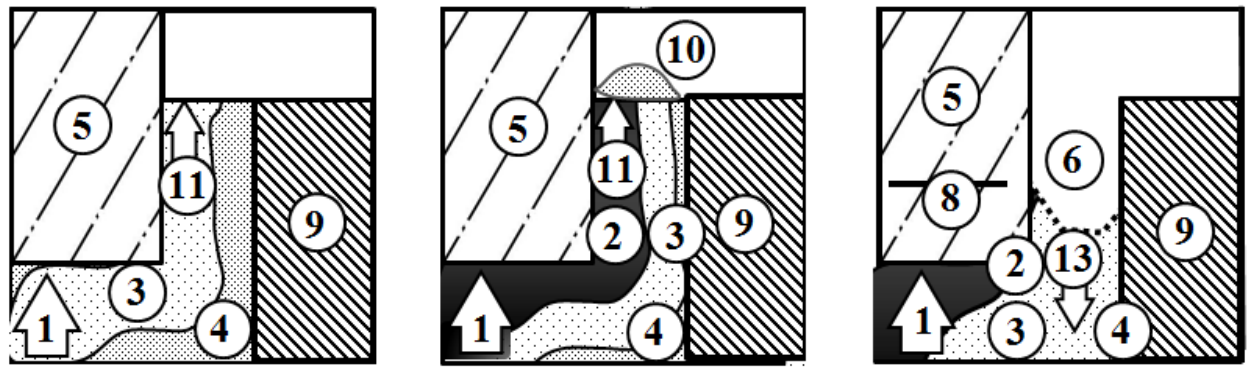

1 - directional water stream; 2 - suffozion channel; 3 - zone of the suffozion decompaction (non-destructive filtration); 4 - soil; 5 - reinforced concrete structure; 6 - sinkhole zone,

8 - zone of potential deformation of the concrete structure; 9 - additional aquiclude; 10 - mud spring; 11 - the direction of removal of particles of a soil to the unloading zone; 13 - direction of shift of the soil mass

Fig. 1. Stages of the development of types of the underground erosion,

$\mathrm{C}-1, \mathrm{C}-2$ and $\mathrm{C}-3$ in the zone of contact with the concrete structure

The development of the suffozion-and-erosive process causes the deformation of the soil massif, which appears on the surface in the form of sinkhole and sedimentations. Partial or complete deformation of the concrete structures takes place. The distinctiveness for the type of the underground erosion C-3, is the pseudo-volcanic form of suffosion, suffosion in the form of mud springs. 


\section{Results}
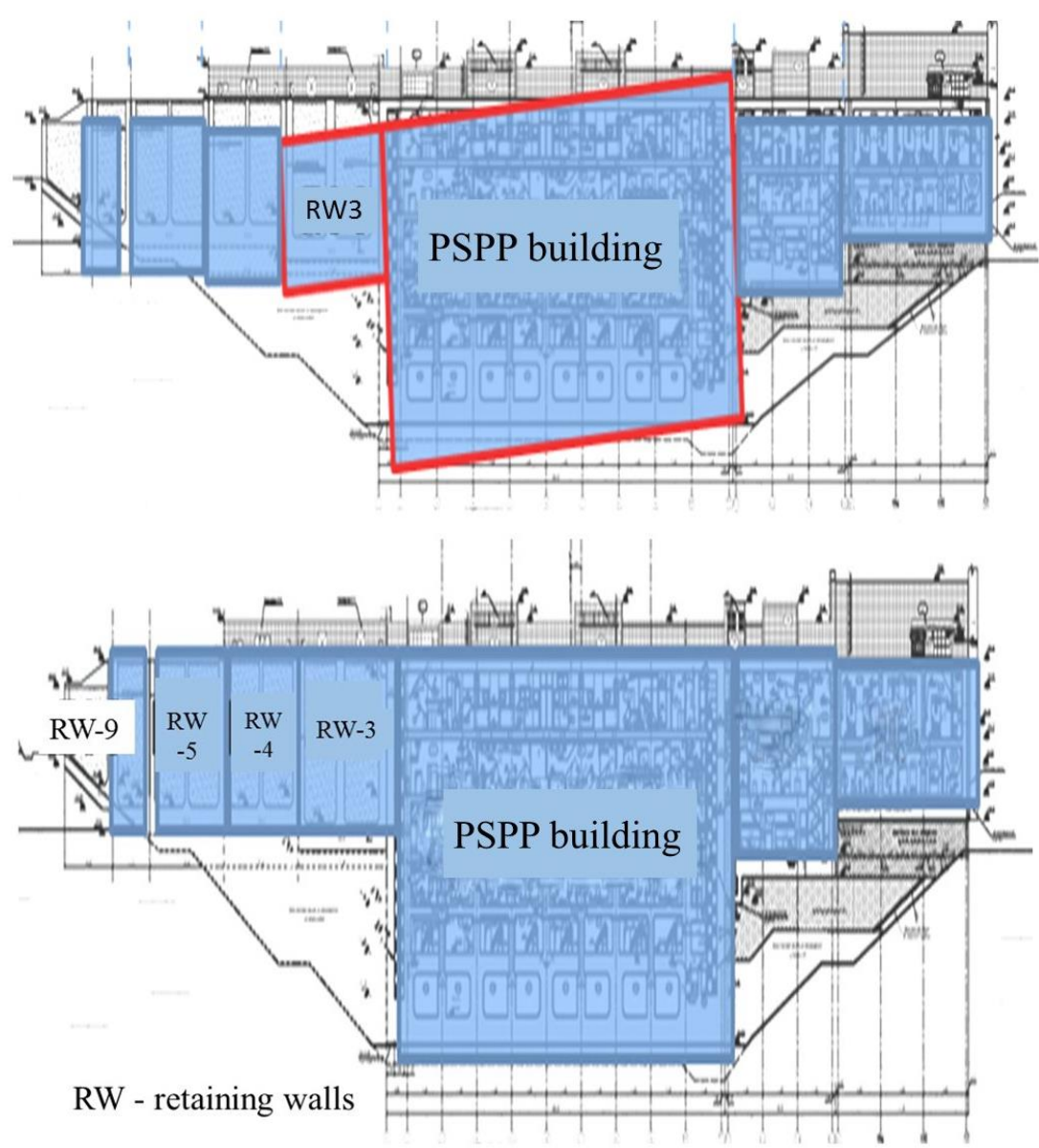

Fig. 2. Scheme of unilateral subsidence of the building ZPSPP-2

(according to the materials, collected by A.V. Alexandrov, E.N. Belendira, etc., 2016) [10]

These types of the underground erosion are illustrated by the example of an accident in 2013, on Zagorsk pumped storage power plant 2 (ZPSPP-2) as the result of which there was the subsidence of a right part of the building of ZPSPP-2 and RW 3 by $1.17 \mathrm{~m}$ (Fig. 2). The region of ZPSPP has difficult engineering-and-geological conditions [11-17].

Unlike operating Zagorsk PSPP-1 it was necessary to consider the influence of the mode of fluctuation of level of the lower (general) pool of Zagorsk pumped storage power plants on the filtrational modes in the basis and antifiltrational contours of ZPSPP-2 during construction of Zagorsk PSPP-2 . Intensive oscillatory process (dumping and raising of the water level up to $9 \mathrm{~m}$ in vertical per a day) (Figure 3) affected the stability of soils of the foundation of the station, reducing their antifiltrational stability. Some researchers prove, that such daily "swing" with change of hydraulic gradient reduced the probability of stabilization of soils of the basis considerably. The continuous, daily change of the intense strained state of the soil massif led to weakening of the structural bonds in breeds and to emergence of the fatigue effect [11-14].

The reason of the plant building subsidence is the removal of soils of the basis of the right part of the base plate of the plant building, which volume is more than 5 thousand $\mathrm{m}^{3}$, via the through underground erosive channel, connecting the water source (the lower canal 
pound) with the area of the removal (the upper canal pound); that was accompanied by the formation of the cavity, which also took a part of the apron and the bulk soils of the backfilling (Figure 3).

Suffosion-and-erosion destruction on the front, continued in the form of discrete-andcyclic erosive and landslide destruction, with the advance of its front in the direction, opposite to the direction of the filtrational stream; that caused the removal of soils from under the apron as well. That made the column of water to break the 1.5 meter apton in the zone of the removal of soils, i.e. the bases of the apron. The volume of the soil, which was taken out from under the apron was about 15 thousand $\mathrm{m}^{3}$., and the total amount of the taken-out material was about 25 thousand $\mathrm{m}^{3}$. (Figure 3 ).

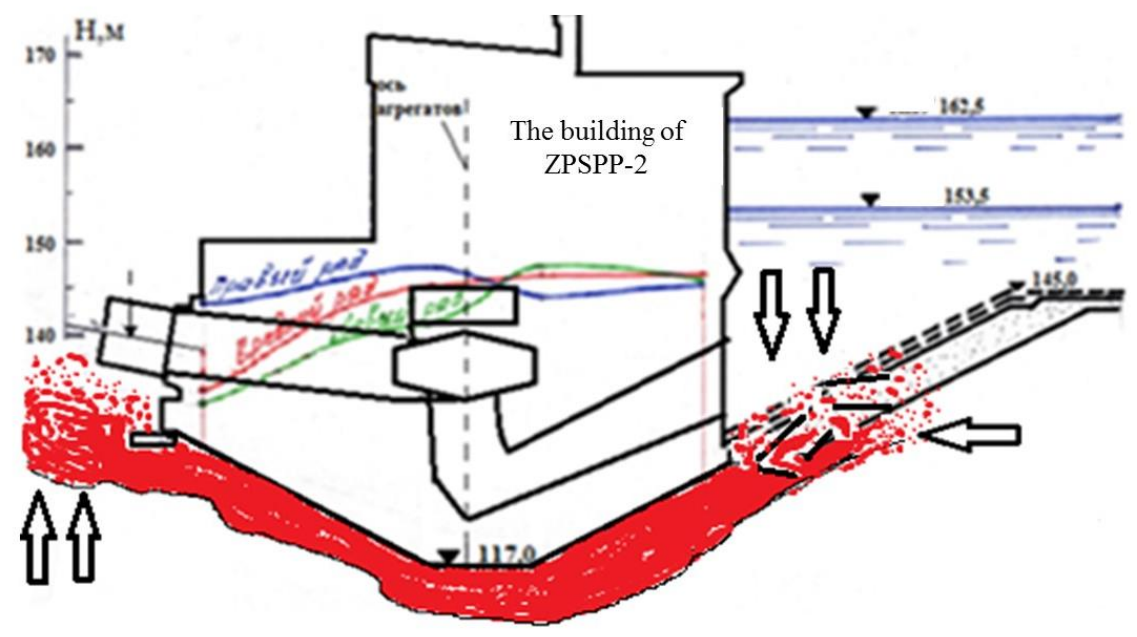

Fig. 3. The underground erosive channel (red color), formed as the result of the long suffosion. As the result of the underground erosion it about 25 thousand $\mathrm{m} 3$ was taken out to the upper canal pound; that caused the uneven subsidence of the ZPSPP-2 building

\section{Conclusions}

1. Even before filling of the pool of the lower canal pound, there were weakened zones in the antifiltrational contour of the lower canal pound in the right part of the foundation of the ZPSPP-2 building. The antifiltrational contour is designed to constrain the water pressure at the level, filled up to the design mark in the lower canal pound. It is necessary to reduce filtration of water and to prevent the development of suffosion, and the subsequent underground erosion (as the result).

2. Unlike the operating Zagorsk PSPP-1 during construction of the Zagorsk PSPP-2 it was necessary to take into account the influence of fluctuations of level of water of the lower (general) pool of the Zagorsk pumped storage power plants on the filtrational modes in the basis and antifiltrational contours of ZPSPP-2. An intensive oscillatory process (dumping and raising of water up to $9 \mathrm{~m}$. down per day) affected on the stability of soils of foundation of the station, reducing their antifiltrational stability.

3. Internal filtrational destruction of water-saturated breeds with the downflow had "a smooth form" and it was certainly connected with slow water percolation from the lower canal pound, through leaky joints or damages to the lining of structures and also insufficiently well functioning antifiltrational contour of the soils of backfilling. The suffusion removal continued the increase in the zone of decompaction and cause the development of the underground erosion as well as the removal of soil of the right-hand 
foundation of the building of the pumped storage power plant. The expansion of the erosive tunnel on the front of the building of the pumped storage power plant from the lower canal pound reached $40 \mathrm{~m}$ with the depth of the seizure of the soil up to 8-10 m. It finally caused the subsidence of the right part of the ZPSPP-2 building and retaining wall RW3 by $1.17 \mathrm{~m}$.

\section{References}

1. A. Lavrusevich, V. Homenko, MGSU Bulletin, 10, 213-220, (2012)

2. I. Lavrusevich, A. Lavrusevich, Materials of the 18th Sergeevsky readings, 150-153 (2016)

3. V. Homenko, Regularities and forecast of suffozionny processes (Moscow, GEOS, 2003)

4. Construction Regulations 116.13330.2012. Engineering protection of territories, buildings and structures against dangerous geological processes. Original positions (Moscow, Ministry of Regional Development of the Russian Federation, 2012)

5. M. Reshetkin, Bulletin of irrigation, 10, 92-96 (1929)

6. A. Lavrusevich, V. Homenko, I. Lavrusevich, Industrial-and-civil engineering, 11, 11-13 (2012)

7. A. Lavrusevich, V. Homenko, I. Lavrusevich, Industrial-and-civil engineering, 11, 54-57 (2015)

8. A. Lavrusevich, Scientific-and-methodical bases of studying and assessment of loessial pseudo-karst in the conditions of a technogenez. Abstract for the degree of Doctor of Technical Sciences (Moscow, 2013)

9. A. Lavrusevich, A. Kabirov etc. Polytechnical Bulletin. Series Engineering research, 4 (40), 158-164 (2017)

10. A. Alexandrov, E. Bellendir, S. Lashchenov, R. Alzhanov, Hydrotechnical construction, 7, 2-10 (2016)

11. A. Demidkova, XVIII Sergeevskiye of reading. Engineering geology and geoecology. Fundamental problems and applied tasks. The anniversary conference devoted to the 25 anniversary of formation of IGE RAS, 267-270 (2016)

12. A. Demidkova, I. Osika,VII scientific-and-technical conference "Hydropower. Advanced designs and technologies" (2012)

13. B. Kochetkov, S. Molodensky, V. Osika, I. Osika, Georisk. 1, 22-28 (2009)

14. I. Osika, Assessment of technogenic impact from work of pumped storage power plant on the geological environment (on the example of the Zagorsk pumped storage power plant). Master's thesis (Moscow, 2009)

15. E. Nasynova, Hydrotechnical construction, 6, 28-32 (2013)

16. S. Golovin, N. Rosenberg, Sergeevsky readings, 263-266 (2016)

17. A. Lavrusevich, MATEC Web of Conferences, 170, 03007 (2018). https://doi.org/10.1051/matecconf/201817003007 